\title{
Customer Relationship Management And Organizational Performance: A Conceptual Framework Based On The Balanced Scorecard (Study Of Iranian Banks)
}

\author{
Elaheh Taghavi Shavazi ${ }^{1}$, Asghar moshabaki ${ }^{2 *}$ (corresponding Author), \\ Seyyed Hamid Khodadad Hoseini ${ }^{3}$, Asadolla Kord Naiej ${ }^{4}$ \\ ${ }^{I}$ Ph.D student of International Marketing, Tarbiat Modares University, Iran \\ ${ }^{2}$ Professor of International Marketing, Tarbiat Modares University, Iran \\ ${ }^{3,4}$ Associate Professor of International Marketing, Tarbiat Modares University, Iran
}

\begin{abstract}
Customers have become crucial for every organization. Due to the competitive environment, customer relationship management (CRM) is one of the important business strategy for companies. Banks can benefit from focusing and concentrating on Customer Relationship Management. There is a stiff competition in the banking industry in Iran. So Iranian banks try to reform their strategies and process to achieve competitive advantage. The customers are an important element that helps the bank to achieve this objective . Banks try to notice the customers requirements and needs for satisfying their customers. Iranian Banks went through reform from product orientation to customer orientation. More importantly, the banks realized that building long-term relationship with their customer is crucial for achieving sustainable competitive advantage and improving performance. This study examined the link between customer relationship management and different measures of performance on the banking sector. Data were collected from the bank sectors in Iran. Based on extensive review of literature, the sub processes in implementing CRM were extracted and also four measures of Balanced scorecard applied to performance. The results indicated that CRM processes are associated with bank performance.

Key words: Customer Relationship Management, Organizational Performance, Initiantion Relationship, Maintenance Relationship
\end{abstract}

\section{Introduction}

In the current organizational environment, customers are crucial elements and place at the central of all marketing actions (Karakostas, Kardaras, \& Papathanassiou, 2005). Recently, consumers' needs and expectations have changed. To notice to various customers and also their needs, organizations want to apply differentiation and customer-oriented marketing strategies for achieving competitive advantage. Customer Relationship Management is one of this marketing strategies that is used to create and manage relationships between organizations and customers more effectively. (Gefen and Ridings, 2002; Ngai, 2005). If organizations try to Improve relationships with their consumers it can leads to have more loyal customers and also increase profitability.

CRM processes are the organizational activities that notice the management of the customer relationship (Moutot \& Bascoul, 2008). Understanding this point that what kinds of CRM activities, can be employed by organizations and how these activities can influence on different measures of performance is important. CRM also is a kind of business strategy that helps banks to identify the most profitable customers and prospects, and allocate attention to expand relationships with customers by making, and customized services that delivered to customers through the various bank channels.

An important question in the implementation of CRM is what is the effect of CRM on organizational performance. So there is a strong tendency for researches to measure the relationship between CRM and different measures of performance.

The contribution of this paper is to conceptualize a framework that shows how different CRM processes will affect on organizational performance measures.

The primary purpose of this article focuses on understanding the relationship between the different CRM processes and different measures of Iranian bank's performance. Two processes of CRM, in this study, which are, Relationship initiation, Relationship maintenance, would be considered. This study examines whether relationship initiation, relationship maintenance have any effect on performance in banks. Performance is defined as financial, customer based, internal process and learning and growth performance.

After review of the literature on CRM and concentration on the process-oriented approach, this research has structured as follows: first, the relationship between CRM process and performance reviewed. After that, the research framework and its dimensions are proposed.Then the research methodology is discussed 
, After that the results of the empirical study were presented. The paper concludes with a discussion, and limitations and some future study directions.

\section{A. Customer Relationship Management (CRM)}

\section{Literature Review}

There are different perspectives about CRM's nature: some authors notice to CRM as a technology, others suggest it is a set of processes that focus on managing the customer experience, some others stress that it is a strategy that increase customer retention.

The process is a collection of tasks or activities that helps organization to achieve to desired business outcomes (Davenport \& Beers, 1995; Hammer, 1996). Organizational strategy should be done by a set of process in order to achieve to desired results by organizations (sable et al., 2004). Some researchers define CRM as a macro level process. It Means it includes some subprocesses, like the identification of prospects and knowledge creation about customers (Srivastava et al., 1999). Some authors also express CRM is the processes that consist of activities that were undertaken by the firms to gain long term, profitable, mutually beneficial customer relationships (Plakoyiannaki \& Tzokas, 2002; Reinartz et al., 2003; Shaw, 2003). Some researchers also said CRM is a cross-functional process. It includes managing customer interactions and identify the most valuable customers and try to personalize activities according to their needs and establish and maintain long-term and profitable relationships ( Day \& Van den Bulte, 2002; Kohli et al., 2001). So, the CRM process is an organizational strategy and has been emphasized (Lindgreen et al., 2006; ).

The studies about CRM can be divided into three different levels like: functional, customer facing, and company wide. Customer-facing level perspective tries to build a single view of the customer across all contact channels and the distribute the customer intelligence to all customer-facing functions .(Werner, Reinartz, 2004) This perspective emphasis on the importance of harmonizing information across time and contact channels in order to manage the all customer relationships. (Reinartz et al, 2004)

Reinartz, Krafft, and Hoyer (2004), Park \& Kim, 2003 expressed CRM at the customer-facing level. They believed CRM is a process and categorize it in three customer relationship stages: relationship initiation, relationship maintenance, and relationship termination that impact the CRM process in order to increase the value and profit of relationship. This research considers Reinartz, Krafft, and Hoyer (2004) and Park \& Kim, 2003 views for determining the CRM measures, but because Reinartz and et al (2004) found no relationship between termination process and performance and also the Iranian banks don,t apply this process as a process of CRM ( based on the Iranian bank's experts view), this study just test two processes of CRM ( initiation and maintenance) and disregard termination process.

\section{B. Organizational performance and Balance score card:}

The balanced scorecard is a management framework which developed by Kaplan and Norton (1992). It is a system that assesses and shows an overall view about organization performance (Ricciardi, E., 2005). BSC tries to consider benefits of all stakeholders such as management, customer, employee and society (Stewart, R.A., Mohamed, S., 2001). Measuring organizational performance just by financial measures is not enough for an organization so the BSC is more noticeable (Huerta, E., Villanueva, F., 2006). One of the most important problems that companies face when they just use financial indexes for measuring their performance is that these indicators do not obviously show how successful an organization will be in the market, how successful it will be within a competitive environment. Kaplan and Norton, (1996) emphasis that BSC is as a temple and it should consistent with special concept in an organization so this research considers this point for measuring the performance. The balanced scorecard translates vision and strategy into four view points. Kaplan and Norton, 1992 believed, these factors reflected the following perspectives of the strategy: Financial; Customer; Internal business processes; and Organisational learning and growth.

This article tries to extract the indicators that are related to each viewpoint about performance based on the literature of CRM and also the experts view.

\section{CRM and Performance}

Different researches have been done about CRM frameworks but there has been limited academic effort about the issue of the CRM process and firm performance. Some researches tried to understand the consequences of CRM (Ryals \& Knox, 2001; Ryals \& Payne, 2001). There is some evidence focus on CRM's impact on organizational performance (Reinartz, Krafft, \& Hoyer, 2003; Day \& Van den Bulte, 2002 ). Different articles showed the positive impact of CRM on different aspects of performance, for example aspects that are related to the company (Palmatier, et al, 2007) or aspect that are related to customers( Gustafsson, Johnson, \& Roos, 2005; Mithas, Krishnan, \& Fornell, 2005).

Reinartz et al. (2004) attempts to relate CRM activities that lead satisfaction to a different business performance measures. There are some other studies that show a relationship between the activity of customer satisfaction 
and business performance (Kamakura, de Rosa, \& Mazzon, 2002). There is also some study that expresses the association between activities that lead to customer loyalty and commitment - profitability and retention (Reinartz \& Kumar, 2000 ; Verhoef, 2003).

Reinartz et al. (2004) also tried to establish a link between CRM and organizational performance. As mentioned before they found CRM has three distinct customer relationship-related stages: initiation, maintenance, and termination. They found CRM has an impact on perceptual performance across the three stages. In the initiation and maintenance stages, some support was found for CRM's impact on Performance, but little support was found for CRM's impact on the termination stage.

Some researchers stress that sales force efficiency and effectiveness will improve by applying the CRM process (Jones, Sundaram, \& Chin, 2002). Rigby et al., 2002 expressed that one potential CRM benefit that did not make the list includes improved employee motivation

LOŠŤÁKOVÁ ,(2007) Believed an organization can Develop time of product modification for a customer compared to competition and increase a number of newly introduced products compared to the competition. She also expressed CRM cause increase sales volume of individual customers and also sales revenue with individual customers. Customer satisfaction and loyalty is as consequences of CRM process too.

K i m, S u h \& w a n g (2003) also suggested a model that emphasizes CRM process can improve customer satisfaction, increase customer loyalty, reduce customer cost and increase customer revenue and profit for organizations.

The length of interaction with customers will be increased and also the time of delivering services to customers will be decreased for organizations that apply CRM (Khirallah, 2004).

La Valle \& Scheld (2004) expressed that CRM can decrease the marketing and sale cost. It can also decrease the customer loose rate and increase customer value.

Customer relationship management helps to improve customer perception about product and service. So it can lead the increment of revenue ( Dutu \& Halmajan, 2011).

Chang (2007) emphasis that customer relationship management can impact on different measures of performance. He showed CRM can decrease the marketing and service cost. The revenue of the company also increases by cross /up selling. CRM process stress on customer segmentation based on customer needs and information. So the company can improve product /service quality.

Ullah \& Al-Mudimigh,2009 and O' Reilly,2000 expressed if companies notice on CRM process, it can help them to increase their profit and also the shareholder revenue. Due to one of the important activities of CRM process is gathering data about current and potential customers and creating a database, so the employee has access to important information about customers and their needs and can improve their service based on their requirements so it can leads employee satisfaction .

Given the above discussion this study hypothesizes that:

$H_{1}$ : There is a positive association between CRM processes and organizational performance.

$\mathrm{H}_{1-1}$ : There is a positive association between initiation relationship and financial performance.

$\mathrm{H}_{1-2}$ : There is a positive association between maintenance relationship and financial performance.

$\mathrm{H}_{1-3}$ : . There is a positive association between initiation relationship and customer based performance.

$\mathrm{H}_{1-4}$ : There is a positive association between maintenance relationship and customer based performance.

$\mathrm{H}_{1-5}$ : There is a positive association between initiation relationship and internal process performance.

$\mathrm{H}_{1-6}$ : There is a positive association between maintenance relationship and internal process performance.

$\mathrm{H}_{1-7}$ : There is a positive association between initiation relationship and learning and growth performance.

$\mathrm{H}_{1-8}$ : There is a positive association between maintenance relationship and learning and growth performance.

\section{Research Model}

The proposed model of this study conceptualizes the relationship between CRM processes and bank performance measures. The relationship is based on the views that suggests the performance of an organization is influenced by CRM processes.This model involves 2 dimensions of CRM processes which include relationship initiation, relationship maintenance and four perspectives of performance which are financial, customer based, internal process, learning and growth. 


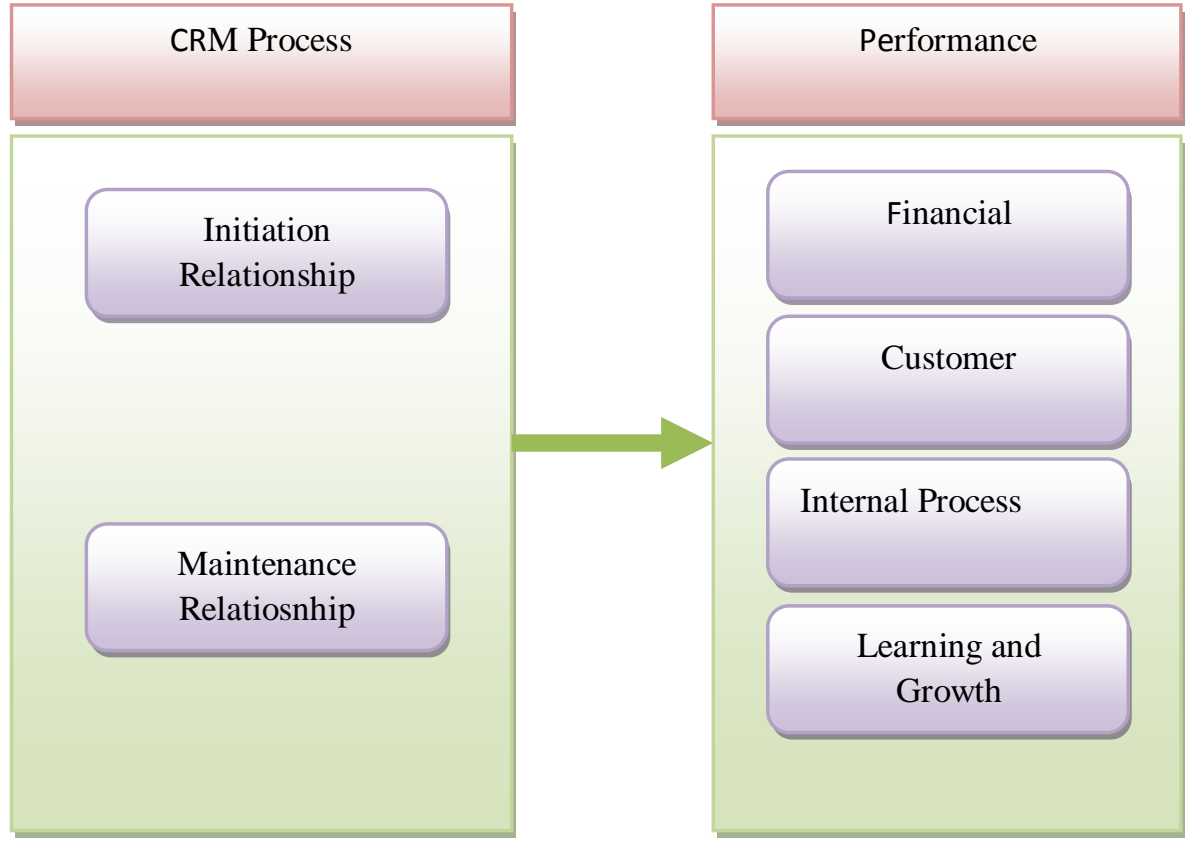

Figure 1: Conceptual Framework

\section{A. Sampling}

\section{Methodology}

This study is a questionnaire survey that combined with a statistical treatment. The sample was composed of 480 questionnaires were distributed among employees. 366 questionnaires were returned and 359 questionnaires were usable and could use for the study.

\section{B. Measurement}

This research defined the domain of each construct to determine what include or exclude. Then with searching the literatures the appropriate scales for measuring the CRM and performance were extracted. Measures of the CRM processes were adapted from Reinartz, Krafft and Hoyer, 2004. Some changes in questions were made based on the view of the experts .

After searching the different literatures and also the expert, $\mathrm{s}$ viewpoints the appropriate scales for assessing the organizational performance were extracted. New scale was designed, A list of defined constructs and measures was then submitted to some experts. Following this, in an attempt to establish the reliability of the measures, a pilot study was conducted among 20 academic and also bank management who deal with such matters. The organizational performance consists of: Financial performance, customer based performance, Internal process performance, learning and growth performance. The Measures of CRM and performance are shown in table1. Measurements of all the constructs were carried out by a 5-point Likert type scale ranging from (1) Strongly Disagree to (5) Strongly Agree.

Table 1: Indicators of construct

\begin{tabular}{|c|c|c|c|}
\hline Construct & Component & Symbol & Indicator \\
\hline \multirow{8}{*}{ 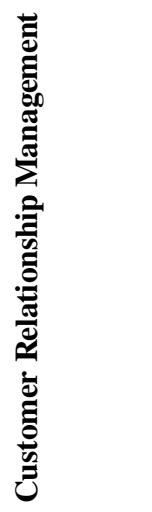 } & \multirow{8}{*}{ 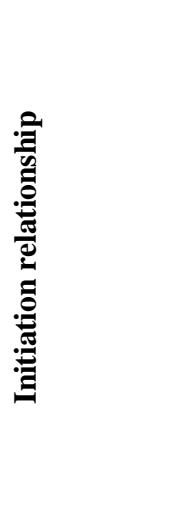 } & IR1 & We have a formal system for identifying potential customers. \\
\hline & & IR2 & $\begin{array}{l}\text { We have a formal system for identifying which of the potential customers are } \\
\text { more valuable. }\end{array}$ \\
\hline & & IR3 & We use data from external sources for identifying potential high value customers \\
\hline & & IR4 & $\begin{array}{l}\text { We have a formal system in place that facilitates the continuous evaluation of } \\
\text { prospects }\end{array}$ \\
\hline & & IR5 & $\begin{array}{l}\text { We have a system in place to determine the cost of re-establishing a relationship } \\
\text { with a lost customer }\end{array}$ \\
\hline & & IR6 & $\begin{array}{l}\text { We have a systematic process for assessing the value of past customers with } \\
\text { whom we no longer have a relationship }\end{array}$ \\
\hline & & IR7 & $\begin{array}{l}\text { We have a system for determining the costs of re-establishing a relationship with } \\
\text { inactive customers. }\end{array}$ \\
\hline & & IR8 & $\begin{array}{l}\text { We made attempts to attract prospects in order to coordinate messages across } \\
\text { media channels }\end{array}$ \\
\hline
\end{tabular}




\begin{tabular}{|c|c|c|c|}
\hline & & IR9 & $\begin{array}{l}\text { We have a formal system in place that differentiates targeting of our } \\
\text { communications based on the prospects value }\end{array}$ \\
\hline & & IR10 & We have a system in place to be able to interact with lost customers \\
\hline & & IR11 & $\begin{array}{l}\text { We have a systematic process for re-establishing a relationship with valued } \\
\text { inactive customers }\end{array}$ \\
\hline & & IR12 & We develop a system for interacting with inactive customers \\
\hline & & MR1 & We maintain an interactive two-way communication with our customers \\
\hline & & MR2 & We actively stress customer loyalty or retention programs \\
\hline & $\stackrel{\varrho}{\check{Z}}$ & MR3 & $\begin{array}{l}\text { We systematically attempt to customize products/services based on the value of } \\
\text { the customer }\end{array}$ \\
\hline & 胥 & MR4 & We systematically attempt to manage the expectations of high value customers \\
\hline & ¿ & MR5 & We attempt to build long-term relationships with our high-value customers \\
\hline & 8 & MR6 & We have formalized procedures for cross-selling to valuable customers \\
\hline & $\Xi$ & MR7 & We have formalized procedures for $u p$-selling to valuable customers \\
\hline & 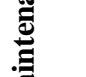 & MR8 & $\begin{array}{l}\text { We provide individualized incentives for valuable customers if they intensify their } \\
\text { business with us }\end{array}$ \\
\hline & $\sum^{\pi}$ & MR9 & We try to actively manage the customer referral process \\
\hline & & MR10 & $\begin{array}{l}\text { We provide current customers with incentives for acquiring new potential } \\
\text { customers }\end{array}$ \\
\hline & & FP1 & After implementing CRM profitability of our bank has increased. \\
\hline & 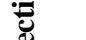 & FP2 & After implementing CRM, return of investment in our bank has increased \\
\hline & $\frac{\pi}{2}$ & FP3 & $\begin{array}{l}\text { After implementing CRM, cost of new customer attraction in our bank has } \\
\text { decreased }\end{array}$ \\
\hline & $\bar{\pi}$ & FP4 & After implementing CRM, Marketing cost in our bank has increased \\
\hline & 冚 & FP5 & $\begin{array}{l}\text { After implementing CRM, CLV(customer lifetime value in our bank has } \\
\text { increased }\end{array}$ \\
\hline & & CP1 & After implementing CRM, our customer satisfaction has increased \\
\hline & $\stackrel{\Xi}{ \pm}$ & $\mathrm{CP} 2$ & After implementing CRM, our customer perception about service has improved \\
\hline & ह छ & CP3 & After implementing CRM, our customer trust about us has increased. \\
\hline$\stackrel{\mathscr{E}}{\Xi}$ & 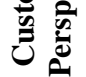 & $\mathrm{CP} 4$ & After implementing CRM, the number of our customers has increased. \\
\hline$\stackrel{0}{0}$ & & IPP1 & After implementing CRM , our activity efficiency has increased. \\
\hline$\stackrel{0}{2}$ & 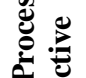 & IPP2 & $\begin{array}{l}\text { After implementing CRM, the process of service delivery in our bank has } \\
\text { improved. }\end{array}$ \\
\hline & 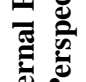 & IPP3 & $\begin{array}{l}\text { After implementing CRM,the process of responding to the customer complaint in } \\
\text { our bank has improved. }\end{array}$ \\
\hline & $\stackrel{\Xi}{\Xi} \approx$ & IPP4 & $\begin{array}{l}\text { After implementing CRM, we try to form most of our banks, s process based on } \\
\text { the customer needs. }\end{array}$ \\
\hline & & LP1 & After implementing CRM, our employee satisfaction has increased. \\
\hline & 承 & LP2 & $\begin{array}{l}\text { After implementing CRM, our bank position in comparison with our competitors } \\
\text { has improved. }\end{array}$ \\
\hline & שุ & LP3 & $\begin{array}{l}\text { After implementing CRM , our bank can influence on important market segments } \\
\text {. }\end{array}$ \\
\hline & & LP4 & After implementing CRM , our services improved continuously \\
\hline
\end{tabular}

\section{Reliability and validity assessments}

In this research, first, exploratory factor analysis loading on the dominant factor were done. It should be at least at 0.5 for each of the measures. Second, the analysis for assessing reliability was conducted (Cronbach, 1951). When the alpha Cronbach is above the 0.70 the reliability is well (Nunnally, 1978). Third, this study did a confirmatory factor analysis (CFA) using maximum likelihood estimation procedures for measure validation based on Gerbing and Anderson (1988). The results show both acceptable model fits and item properties . The overall model fit Indices, Chi square/degree of freedom, adjusted goodness of fit index(AGFI),comparative fit index(CFI), and root mean square error of approximation(RMSEA) indicate acceptable model fits.( see table 6)

\section{Exploratory Factor analysis:}

Kaiser-Meyer-Olkin (KMO) measures of sampling adequacy and Bartlett"s test of sphericity should be used to test whether the factor analysis is appropriate or not (Marinova et al., 2011). The KMO measures of sampling adequacy for CRM is 0.73 and the Bartlettes test of sphericity for CRM is 0.000 that is significant 
because when the KMO is more than 0.5 and the Bartlettes test of sphericity is less than 0.05 and also the result of factor loading in more than 0.5 so the results of factor analysis are acceptable for CRM construct( See Table 2 and 3 )

Table 2: KMO and Bartlett,s Test Result For CRM

\begin{tabular}{|c|c|}
\hline KMO & 0.703 \\
\hline Bartlett,s Test Approx.Chi-Squar & $1.144 \mathrm{E} 3$ \\
Sig. & 0.000 \\
\hline
\end{tabular}

Table 3 :Exploratory Factor Analysis Results for CRM

\begin{tabular}{|l|c|c|}
\hline & IR & MR \\
\hline IR1 & .501 & .118 \\
\hline IR2 & .567 & .139 \\
\hline IR3 & .525 & .191 \\
\hline IR4 & .654 & .319 \\
\hline IR5 & .770 & .270 \\
\hline IR6 & .824 & .125 \\
\hline IR7 & .800 & .202 \\
\hline IR8 & .739 & .357 \\
\hline IR9 & .51 & .330 \\
\hline IR10 & .599 & .158 \\
\hline IR11 & .553 & .220 \\
\hline IR12 & .625 & .207 \\
\hline MR1 & .181 & .814 \\
\hline MR2 & .111 & .704 \\
\hline MR3 & .076 & .746 \\
\hline MR4 & .098 & .743 \\
\hline MR5 & .269 & .677 \\
\hline MR6 & .265 & .789 \\
\hline MR7 & .274 & .802 \\
\hline MR8 & .269 & .823 \\
\hline MR9 & .274 & .688 \\
\hline MR10 & .269 & .751 \\
\hline
\end{tabular}

For organizational performance the KMO is 0.762 and the Bartlett,s test of sphericity is 0.000 . Based on these results, this factor analysis is confirmed as applicable data, and all of the factors are valuable data (See table 4$5)$.

Table 4: KMO and Bartlett, s result of performance

\begin{tabular}{|c|c|}
\hline KMO & 0.762 \\
\hline Bartlett,s Test Approx.Chi-Squar & $1.144 \mathrm{E} 3$ \\
Sig. & 0.000 \\
\hline
\end{tabular}


Table 5: Exploratory factor analysis of performance

\begin{tabular}{|l|c|c|c|c|}
\hline & \multicolumn{4}{|c|}{ Components } \\
\hline & FFP & CP & IPP & LP \\
\hline FP1 & .838 & .118 & .125 & .043 \\
\hline FP2 & .863 & .124 & -.094 & .021 \\
\hline FP3 & .700 & .221 & .099 & .076 \\
\hline FP4 & .776 & .224 & .041 & .149 \\
\hline FP5 & .795 & .024 & .143 & .052 \\
\hline CP1 & .074 & .800 & .134 & .260 \\
\hline CP2 & .062 & .857 & .304 & .092 \\
\hline CP3 & .190 & .830 & .145 & .018 \\
\hline CP4 & .073 & .643 & .120 & .002 \\
\hline CP5 &. .181 & .812 & .057 &. .114 \\
\hline IPP1 & .176 & .173 & .876 & .149 \\
\hline IPP2 & .089 & .104 & .789 & .153 \\
\hline IPP3 & .209 & .078 & .739 & .133 \\
\hline IPP4 & .165 & .053 & .865 & .052 \\
\hline LP1 & .224 & .232 & .152 \\
\hline LP2 & .059 & .111 & .102 \\
\hline LP3 & .115 & .096 & .138 & .861 \\
\hline LP4 & .074 & .008 & .149 & .742 \\
\hline & & & & .855 \\
\hline
\end{tabular}

This study also investigated whether all the factors are reliable. A reliability coefficient of 0.70 or higher is "acceptable" in most research situations (Nunnally, 1978).

In this paper, the Cronbach alpha for CRM is 0.824 and also for organizational performance is 0.711 which is acceptable. (Nunnally, 1978).

\section{Findings}

In this paper, in order to study the influence of independent variable (CRM) and dependent variables (organization performance), regression factor analysis are used. The results of these tests are illustrated below.

According to table 6, CRM processes have a positive effect on organizational performance. So the main hypotheses of this study were accepted $(t-v a l u e=11.89>2)$

Table 6: Main hypothesis result

\begin{tabular}{|c|c|c|c|}
\hline Result & t- value & $\begin{array}{c}\text { Path } \\
\text { coefficient }\end{array}$ & Main Hypothesis \\
\hline Accepted & 11.89 & 0.75 & $\begin{array}{c}\text { CRM process and } \\
\text { organizational performance }\end{array}$ \\
\hline \multicolumn{2}{|c|}{$\chi^{2}=12.67 \quad \mathrm{df}=13$ RMSEA $=0.000 \quad \mathrm{GFI}=0.98 \quad \mathrm{AGFI}=0.96$} \\
\hline
\end{tabular}

The results of all secondary hypotheses are summarized in the table below.

Table 7: The results of secondary hypothesis

\begin{tabular}{|c|c|c|lc|}
\hline Result & T-value & Path coefficients & \multicolumn{2}{|c|}{ Secondary hypothesis } \\
\hline Accepted & 9.46 & 0.62 & $\begin{array}{l}\text { Relationship initiation and Financial } \\
\text { performance }\end{array}$ \\
\hline Accepted & 8.05 & 0.54 & $\begin{array}{l}\text { Relationship initiation and } \\
\text { performance }\end{array}$ \\
\hline Accepted & 6.25 & 0.41 & $\begin{array}{l}\text { Relationship initiation and and } \\
\text { performance }\end{array}$ \\
\hline Accepted & 3.58 & 0.28 & Relationship initiation and Learning and growth \\
\hline
\end{tabular}




\begin{tabular}{|c|c|c|lc|}
\hline & & & performance & \\
\hline Accepted & 18.68 & 0.95 & $\begin{array}{l}\text { Relationship maintenance and Financial } \\
\text { performance }\end{array}$ \\
\hline Accepted & 16.86 & 0.89 & $\begin{array}{l}\text { Relationship maintenance and Customer based } \\
\text { performance }\end{array}$ \\
\hline Accepted & 7.98 & 0.51 & $\begin{array}{l}\text { Relationship maintenance and Internal process } \\
\text { performance }\end{array}$ \\
\hline Accepted & 7.37 & 0.48 & Relation and Learning and growth performance \\
\hline
\end{tabular}

As the table above shows all of the secondary hypotheses were accepted. The results show the maintenance relationship process has the most effect on financial performance $(0.95)$ and customer based performance $(0.89)$. The less effect is the relationship between initiation relationship process and learning and growth performance( 0.28$)$.

\section{Conclusion}

The objective of this study was to investigate the effect of CRM perocess on organizational performance based on four measures of balance scorecard. Initiation relationship and maintenance relationship were selected as measures of CRM. Our results are generally in line with expectations and provide empirical support for our proposed model specification. Results indicate that both components of CRM are significant predictors of all performance measures. This is true for all 4 indicators of performance: financial, customer based, internal process and learning and growth. In view of these results, it may be useful for managers keep track of changes in the CRM process in addition to monitoring different measures of their performance.

The results of this study also provide important marketing and strategic implications for the banking industry. As mentioned before The findings generally confirm the overall hypothesis that there is a significant relationship between CRM process and bank performance. Therefore, it is very important for managers to notice different processes and activities of CRM in banks. Bank management should understand who is the valuable potential customer, what kind of service and product they need, why the customer connects to competitors, how they can retain loosing customers, how they can attract valuable customer to increase their performance, They also should try to have a long term relationship with their current customer, try to persuade them to use from another service of the bank, notice to customer complaint and try to solve their problem as soon as possible, Persuade customer to have an idea about the products or service and referring new customer to the bank. In turn, improvements these constructs can improve the link between CRM and performance. Without this understanding, it is hard for a bank to determine the specific actions about its CRM that are likely to lead to the greatest different measures of performance.

To sum, the present study has managed to provide some important insight about the influence of CRM processes on on different measures of performance based on the balanced scorecard. In addition, the findings about the relationship of two processes of relation initiation and maintenance relationship with performance are matched with previous empirical studies .

\section{Limitation}

This study was subject to a number of limitations. One limitation of this research is that it is based on 366 bank employee respondents. It did not allow the researchers to apply their findings to the entire population. Further, the targeting bank consists of private and also governmental bank, which the result maybe are much different if this study noticed these banks separately.

\section{Recommendations for future research}

It is recommended that future researchers can enlarge the sample size and also compare the result of the private and governmental banks and express the differences.

Future researchers also can attempt to replicate this study in other service industries, for example the transport (airlines) or hospitality (restaurants) industries, and compare the results thereof future studies.

\section{References}

[1] Ajay Kumar Behera, A. K., Nayak, N. C. \& Das, H. C. (2013). “ A study on customer relationship management (CRM) \& bank performance using IT", IJAET, Vol. 4, No.1, pp. 9-13

[2] Arth Prabhand A. (2012). “ Customer relationship management in banking sector: A comparative study of SBI and other nationalitied commercial banks in India" Journal of Economics and Management, Vol.1, No. 6 ,

[3] Cao, Y., \& Gruca, T. S. (2005). "Reducing adverse selection through customer relationship management", Journal of Marketing, Vol.69, No.4, pp.219-229.

[4] Coltman, T. R. (2006). "Where are the benefits in CRM technology investment? "Proceedings of the 39th Hawaii International Conference on System Sciences, Hawaii, USA. 
[5] Cronbach, L. J. (1951). “Coefficient alpha and the internal structure of tests” ,Psychometrika, Vol.16, No. 3, pp.297-334

[6] Davenport, T. H., \& Beers, M. C. (1995). "Managing information about processes" Journal of Management Information Systems, Vol.12, pp.57-80.

[7] Day, G. S., \& Van den Bulte, C. (2002). "Superiority in customer relationship management: Consequences for competitive advantage and performance" Working paper, Wharton School of Economics, University of Pennsylvania

[8] Dutu, C., Halmajan, H. (2011). "The Effect of Organizational Readiness on CRM and Business Performance", International Journal of Computers, Vol.1, No.2, pp. 106-114.

[9] Dwyer, F. R., Schurr, P. H., \& Oh, S. (1987). “Developing buyer-seller relationship” Journal of Marketing, Vol.51, No.2, pp. 11-27.

[10] Gefen D, Ridings M. C.(2002). "Implementation team responsiveness and user evaluation of customer relationship management: a quasi-experimental design study of social exchange theory”, J Manage Inf Syst, Vol.19, No.1, pp.4770.

[11] Gerbing, D. W., \& Anderson, J. C. (1984). "On the meaning of within-factor correlated measurement errors", Journal of Consumer Research, Vol. 11, pp. 572-580.

[12] Gustafsson, A., Johnson, M. D., \& Roos, I. (2005). "The effects of customer satisfaction, relationship commitment dimensions, and triggers on customer retention", Journal of Marketing, Vol.69, No.4, pp. 210-218.

[13] Hammer, M. (1996). "Beyond Reengineering: How The Process-Centered Organization Is Changing Our Work And Our Lives" New York: HarperCollins

[14] Huerta, E., Villanueva, F. (2006). “ The Balanced Scorecard to Measure Information Technology Performance: Work in Progress", Proceedings the 7 th annual Conference of the Southern Association for information systems, (SAIS), Savannah, Georgia, USA, February 27-28,

[15] Jones, E., Sundaram, S., \& Chin, W. (2002). "Factors leading to sales force automation use: a longitudinal analysis.", Journal of Personal Selling and Sales Management, Vol. 22, No.3, pp. 145-156.

[16] K i m, J. S u h, E., \& w a n g, H.( 2003). "A model for evaluating the effectiveness of CRM using the balanced scorecard" journal of Interactive Marketing, Vol. 17, No. 2

[17] Kamakura,W. A., Mittal, V., de Rosa, F., \& Mazzon, J. A. (2002). “Assessing the service profit chain. Marketing Science”, Vol. 21,No.3, pp.294-317.

[18] Kaplan, R.S. \& Norton, D.P. (1992). "The balanced scorecard-measures that drive performance", Harvard Business Review, Vol.70, No.1/2), pp.71-79.

[19] Kaplan, R.S.\&Norton, D.P. (1996). "Linking the Balanced Scorecard to Strategy", California management review, Vol. 39, No. 1, pp. 53- 79.

[20] Karakostas, B., Kardaras, D., \& Papathanassiou, E. (2005). "The state of CRM adoption by the financial services in the UK: an empirical investigation", Information \& Management, Vol.42, No.6, pp.853-863.

[21] Kohli, R., Piontek, F., Ellington, T., VanOsdol, T., Shepard, M., \& Brazel, G. (2001). "Managing customer relationships through ebusiness decision support applications: A case of hospital- physician collaboration”, Decision Support Systems, Vol.32, No.2, pp. $171-187$.

[22] Lavalle,s. \& and Brian S. (2004). "CRM Done Right: Executive Handbook for Realizing the Value of CRM", IBM Business Consulting Services, http://www-1.ibm.com/services/us/index.wss/ summary/bcs/a1002689

[23] Lindgreen, A., Palmer, R., Vanhamme, J., \& Wouters, J. (2006). "A relationship management assessment tool: Questioning, identifying, and prioritizing critical aspects of customer relationships", Industrial Marketing Management, Vol.35, No.1, pp. 57-71.

[24] LOŠŤÁKOVÁ, H. (2007). "BALANCED SCORECARD MODIFICATION WHILE APPLYING CRM STRATEGY", VADYBA / MANAGEMENT. Vol. 3, No. 4, pp.16-17

[25] Marinova, M. M., Aharonson, O., \& Asphaug, E. (2008). "Mega-impact formation of the Mars hemispheric dichotomy", Nature, Vol.453, No.7199, pp. 1216-1219.

[26] Mithas, S., Krishnan, M. S., \& Fornell, C. (2005). "Why do customer relationship management applications affect customer satisfaction?" Journal of Marketing, Vol.69, No.4, pp.201-209

[27] Moutot, J. M., \& Bascoul, G. (2008). "Effects of sales force automation use on sales force activities and customer relationship management processes", Journal of Personal Selling and Sales Management, Vol. 28, No. 2, pp. 167-184.

[28] EWT, N. (2005). "Customer relationship management research", Mark Intell Plann Vol.23, No.6, pp.582-605.

[29] Niraj, R., Gupta, M., \& Narasimhan, C. (2001). "Customer profitability in a supply chain” Journal of Marketing, Vol.65, pp.1-65.

[30] Palmatier, R. W., Scheer, L. K., Houston, M. B., Evans, K. R., \& Gopalakrishna, S. (2007). "Use of relationship marketing programs in building customer-salesperson and customer-firm relationships: Differential influences on financial outcomes", International Journal of Research in Marketing, Vol.24, No. 3, pp. 210-223

[31] Park, C. H., \& Kim, Y. G. (2003). "A framework of dynamic CRM: Linking marketing with information strategy", Business Process Management Journal, Vol.9, No.5, pp.652-671.

[32] Plakoyiannaki, E., \& Tzokas, N. (2002). "Customer relationship management: A capabilities portfolio perspective", Journal of Database Marketing, Vol.9, No.3, pp. 228-237.

[33] Reinartz, W. J., Krafft, M., \& Hoyer, W. D. (2003).” Measuring the customer relationship management construct and linking it to performance outcomes" Working Paper Series of the Teradata Center for Customer Relationship Management, Duke University

[34] Reinartz, W., \& Kumar, V. (2000). "On the profitability of long lifetime customers: An empirical investigation and implications for marketing", Journal of Marketing, Vol. 64, pp.17-35.

[35] Reinartz, W., Krafft, M., \& Hoyer, W. D. (2004), “The customer relationship management process: Its measurement and impact on performance", Journal of Marketing Research, XLI, 293-305. 